Kansas State University Libraries

New Prairie Press

\title{
Radical Questioning on the Long Walk to Freedom: Nelson Mandela and the Practice of Critical Reflection
}

Stephen Brookfield

University of St. Thomas, USA

Follow this and additional works at: https://newprairiepress.org/aerc

Part of the Adult and Continuing Education Administration Commons

(c) (1) (9)

This work is licensed under a Creative Commons Attribution-Noncommercial 4.0 License

\section{Recommended Citation}

Brookfield, Stephen (2007). "Radical Questioning on the Long Walk to Freedom: Nelson Mandela and the Practice of Critical Reflection," Adult Education Research Conference. https://newprairiepress.org/aerc/ 2007/papers/16

This is brought to you for free and open access by the Conferences at New Prairie Press. It has been accepted for inclusion in Adult Education Research Conference by an authorized administrator of New Prairie Press. For more information, please contact cads@k-state.edu. 


\title{
Radical Questioning on the Long Walk to Freedom: Nelson Mandela and the Practice of Critical Reflection
}

\author{
Stephen Brookfield \\ University of St. Thomas, USA
}

\begin{abstract}
This paper examines the autobiography of Nelson Mandela Long Walk to Freedom. Using a formulation of critical reflection as the deliberate uncovering and challenging of assumptions concerning power and hegemony, Long Walk to Freedom is subjected to a thematic content analysis using the analytical heuristic of critical reflection.
\end{abstract}

Long Walk to Freedom can be analyzed as a chronicle of critical reflection in practice, if we understand this process in a politicized way as the uncovering and exploration of assumptions concerning power dynamics and the maintenance of ruling class hegemony. The book describes how an iconic political activist and freedom fighter reflected on, and sometimes modified, several core assumptions at the heart of his struggle to overturn the White supremacist, minority hegemony and create a free South Africa. These assumptions were either completely upended or significantly altered as a result of being reviewed through various critically reflective lenses that are similar to the lenses central to the reflective process. Mandela used four lenses on his practice as a freedom fighter and then President in waiting; he constantly reviewed his autobiographical experiences as a freedom fighter, he relied on the lens of his colleagues' (particularly his fellow ANC executive committee members) perceptions, he sought out the lens of literature (particularly radical literature on political economy and the raising and training of a guerilla army), and he was committed to regularly consulting the lens of ANC (African National Congress) members' eyes. Although clearly unaware of adult education's utilization of this term, Mandela's reasoning on tactics and strategy, his awareness of the need to reappraise assumptions that previously were viewed as gospel, and his use of multiple lenses through which to view his actions as a freedom fighter, exemplify the practice of critical reflection. Mandela's engagement in critical reflection on the four core assumptions analyzed in this article was resonant with implications for millions of South Africans, and for others across the globe engaged in a struggle for liberation against the remnants of colonialism. It is hard to imagine an example of critically reflective adult learning that has greater significance.

\section{Assumption (1): The Struggle for Black Liberation Must be Conducted by Black South Africans Alone}

The first assumption explored by Mandela is his belief that the movement for a free South Africa must be one in which only Black South Africans should be involved; specifically, his belief that the African National Congress (ANC) should not admit Whites as members, nor cooperate with White groups (such as the South African Communist Party) that were also dedicated to the dismantling of apartheid. This assumption was based on Mandela's belief that the stain of racism had spread so deep into African consciousness that Whites would inevitably come to be seen as leaders within the ANC and occupy leadership positions. Mandela argued to his ANC comrades 
that if Whites were initially involved as equals in the movement, this early equality would quickly be superceded by Whites moving into leadership positions. One reason for this trend, he argued, was the unconscious perception of White superiority held by Blacks who would be subliminally predisposed to defer to White ideas. Hence, "if blacks were offered a multiracial form of struggle, they would remain enamored of white culture and prey to a continuing sense of inferiority” (Mandela, 1994, p. 100).

Mandela was also suspicious of Whites’ intent, particularly White Communists, who he believed "were intent on taking over our movement in the guise of joint action" (p. 108). He also had an Africentric skepticism of the relevance of a Marxist analysis to the African liberation struggle. His belief at this time in his life was that "it was an undiluted African nationalism, not Marxism or multiracialism, that would liberate us" (p. 108). In 1947 the Youth League of the ANC produced a major policy document that called for "a powerful national liberation movement under the banner of African nationalism and led by Africans themselves” (p.112). Mandela notes that the contents of the document were contested, reflecting "the push-and-pull between two rival theories of African nationalism, between the more extreme, Marcus Garvey-inspired, 'Africa for the Africans' nationalism and the Africanism of the Youth League, which recognized that South Africa was a multiracial country" (p. 112). His own position was that "I was sympathetic to the ultra-revolutionary stream of African nationalism” (p.112).

In the decade after the forming of the Youth League, however, Mandela experienced a number of events that caused him to revise his earlier assumption that the liberation struggle should be the preserve only of Black South Africans. The first of these was his numerous conversations with South African Communist Party members such as Moses Kotane, Ismail Meer and Ruth First. Here the lens of colleagues’ perceptions is clearly described. Mandela reflects on how, in the 1940's "I was far more certain in those days of what I was against than what I was for” (p. 119). He describes how Kotane would come to his house late at night and the two of them would debate until morning. As a result of these conversations, Mandela found that "my long-standing opposition to communism was breaking down" (p. 119) and that "I was finding it more and more difficult to justify my prejudice against the party” (p. 119). He noted how party members who were also ANC members (such as J.B. Marks, Edwin Mofutsanyana, Dan Thoome and David Bopape) "were devoted and hardworking, and left nothing to gainsay as freedom fighters” (1994, 120). This means that Mandela "could not, and no longer did, question the bona fides of such men and women” (p. 120).

Having had his skepticism of communists weakened through conversation and observation, Mandela was prompted to initiate a self-directed study of dialectical materialism. Here, the role of literature as an aid to challenging assumptions is front and center. He describes reading Marx, Engels, Lenin, Stalin and Mao and being stimulated by the Communist Manifesto and exhausted by Das Kapital. He records how he found himself drawn to the idea of a classless society, which, to his mind, "was similar to traditional African culture where life was shared and communal. I subscribed to Marx's basic dictum, which has the simplicity and generosity of the Golden Rule: "From each according to his ability; to each according to his needs” (p.120). In the manner of Angela Davis (1974) who wrote how The Communist Manifesto hit her "like a bolt of lightning" (p. 109) Mandela found that "Dialectical materialism seemed to offer both a searchlight illuminating the dark night of racial oppression and a tool that could be used to end it. It 
helped me to see the situation other than through the prism of white and black relations, for if our struggle was to succeed, we had to transcend black and white” (Mandela, 1994, p. 120). He documents how the quasi-scientific underpinnings of dialectical materialism attracted him since, in his words "I am always inclined to trust what I can verify. Its materialistic analysis of economic rang true to me” (p. 120). He also found in his reading of these texts a number of practical suggestions that seemed to him helpful to the struggles he was conducting. Finally, the Soviet Union's support for anti-colonial struggles in Asia and Africa, explained "why I amended my views of communists and accepted the ANC view of welcoming Marxists into its ranks" (p. 121).

As well as holding numerous conversations with Communists, and his own studies in dialectical materialism, Mandela was also prompted to re-examine his assumptions about working with Communists after reflecting on his own autobiographical experiences. The success of the mass action of March 1950, where over two thirds of African workers stayed at home, was clear to Mandela, and he was forced to acknowledge that Communists had played a significant part in planning and conducting this mass action. The fact that the government too recognized the pivotal role of the Communist Party in fomenting successful mass action was indicated by the fact that a few weeks later it passed the Suppression of Communism Act, a development that caused Mandela to declare that "clearly, the repression of any one liberation group was repression against all liberation groups" (p. 117). He noted the prophetic words of Oliver Tambo (for many years head of ANC in exile) "Today it is the Communist Party. Tomorrow it will be our trade unions, our Indian Congress, our APO, our African National Congress" (p. 117).

By the 1950s, then, Mandela had overturned his earlier assumption that the ANC struggle was best conducted by Black South Africans alone, and that Whites, particularly White Communists, would inevitably take the movement over. He had found there to be no contradiction between African nationalism and dialectical materialism. In his view "Our problems, while distinctive and special, were not entirely unique, and a philosophy that placed those problems in an international and historical context of the greater world and the course of history was valuable .... I found that African nationalists and African Communists generally had far more uniting them than dividing them” (p. 121).

By the time of his statement at his trial in Rivonia in 1963 and 1964, he had come to a fully elaborated rationale for his decision to work with the Communist Party. In his own words "It is true that there has often been close cooperation between the ANC and Communist Party. But cooperation is merely proof of a common goal - in this case the removal of white supremacy - and is not proof of a complete community of interests" (p. 366). In explaining why the ANC viewed Communist Party members as friends, Mandela stated "to us the reason is obvious. Theoretical differences amongst those fighting against oppression is a luxury we cannot afford at this stage. What is more, for many decades Communists were the only political group in South Africa who were prepared to treat Africans as human beings and their equals; who were prepared to eat with us; talk with us, live and work with us. Because of this, there are many Africans who, today, tend to equate freedom with communism" (p. 366). Twenty years later, when engaged in secret negotiations with the government who were insisting he cut ties with the Communist Party, he repeated the same argument: "I said, no self-respecting freedom fighter would 
take orders from a government he is fighting against or jettison a longtime ally in the interest of pleasing an antagonist” (Mandela, 1994, p. 538).

\section{Assumption \# 2 Non-Violent Struggle Was Most Likely to Bring About the End of Apartheid}

A second assumption concerns Mandela's initial belief that a nonviolent strategy for political change that focused on mass civil disobedience was the most effective weapon in the struggle against apartheid. Mandela's approach to the struggle was always dictated by a pragmatic concern to experiment with whatever means might speed the end of apartheid. To that end his first years as an activist were spent pursuing various paths of non-violent resistance. These included strikes, boycotts, contraventions of the pass laws (that determined where Black South Africans could travel) and stay at homes. Mandela analyzed the situation facing Black South Africans and determined that tactical considerations, rather than a moral commitment to non-violence, dictated this strategy. Writing about the various discussions he had held on how best to put pressure on the South African regime he summarizes his position thus: "We should approach this issue not from the point of view of principles but of tactics, and (that) we should employ the method demanded by the conditions. If a particular method or tactic enabled us to defeat the enemy, then it should be used” (p. 127).

From Mandela's position "stay-at-homes allowed us to strike at the enemy while preventing him from striking back. I argued that the confidence of the people in our campaigns had grown precisely because they realized that we were not reckless with their lives” (Mandela, p. 266). This desire to avoid bloodshed governed much of Mandela's early thinking and was the chief reason why he put so much emphasis on non-violence. In his view "the state was far more powerful than we, and any attempts at violence by us would be devastatingly crushed. This made nonviolence a practical necessity rather than an option” (p. 127). To Mandela, then, nonviolence was a tactic to be used as long as the situation demanded it. Once it ceased to be effective, by implication, it would be replaced with an approach that made more sense in any new circumstances. There was none of the moral commitment to nonviolence that one associates with Gandhi or Martin Luther King. To Mandela if something worked it would be used, if not it would be abandoned.

In the face of ever more repressive action by the South African apartheid regime, Mandela was forced to rethink his whole strategy for the establishment of democracy in South Africa, a period of questioning that ultimately led to him spending most of his adult life in prison and wrecking any chance of his enjoying a normal family life. Claiming that the government's actions had forced his hand, Mandela moved reluctantly to urge the ANC to take up arms, in particular to conduct a campaign of sabotage against power stations, arms depots and communications networks. On the wider political stage the move to begin a campaign of sabotage against government and military targets ushered in an era of even greater repression and the deaths of many on both sides of the struggle. This new assumption that the armed struggle was now the most effective tactic for achieving long-term change was itself subject to critical reflection many years later.

In questioning his earlier assumption Mandela argued that the conditions faced both by Gandhi and King were strikingly different from those faced by freedom fighters in South Africa. India was ruled by an overstretched colonial power that had accepted the ultimate inevitability of self-rule. The USA was a democracy with constitutional 
guarantees of equal rights, even if these were abused in practice. No such guarantees were available in the police state of South Africa. In his view, "Non-violent passive resistance is effective as long as your opposition adheres to the same rules as you do. But if peaceful protest is met with violence, its efficacy is at an end. For me, nonviolence was not a moral principle but a strategy; there is no moral goodness in using an ineffective weapon” (p. 158). From this point on a repeated theme in Mandela's work was the way in which his tactics - particularly the move to armed resistance - was forced on him by the government's actions. For example, when meeting two editors from the Washington Post in 1984, Mandela professed his Christianity but argued that "Even Christ... when he was left with no alternative, used force to expel the moneylenders from the temple. He was not a man of violence, but had no choice but to use force against evil” (p. 521).

All his adult life - from his work as a lawyer, through to his going underground, during his imprisonment, and in his conversations with the apartheid government Mandela argued that freedom fighting tactics were always dictated by, and responsive to, government actions. This lesson springs entirely from his examination of the struggle through the critically reflective lens of autobiographical experience. His experience as a freedom fighter taught him "the hard way that it is the oppressor who defines the nature of the struggle, and the oppressed is often left no recourse but to use methods that mirror those of the oppressor. At a certain point, one can only fight fire with fire” (Mandela, p. 164). In 1985, when the government secretly tried to pressure him to declare the end of the armed struggle "I responded that the state was responsible for the violence and that it is always the oppressor, not the oppressed, who dictates the form of the struggle. If the oppressor uses violence, the oppressed have no alternative but to respond violently. In our case it was simply a legitimate form of self-defense” (p. 537).

The experience of being despised as an outlaw also taught him how the dynamics of the struggle are defined by external forces. His own outlaw status was not one he sought, but one forced upon him since "When a man is denied the right to live the life he believes in, he has no other choice but to become an outlaw” (1994, p. 256). The decision by the ANC in 1961 to move to armed struggle as a matter of policy was one of the most significant of his life. Ironically, given the accusations that the ANC was a Communist pawn or front organization, this decision was opposed by the South African Communist party. In argument with Moses Kotane (secretary of the South African Communist Party) Mandela admonished Kotane for waiting for the text-book revolutionary conditions advocated by Lenin and Stalin to occur. To Mandela "Castro did not wait, he acted - and he triumphed. If you wait for textbook conditions, they will never occur” (p. 271).

The way in which Mandela examined and changed his assumption regarding the effectiveness of nonviolence illustrated his capacity to alter his exercise of leadership in response to changing circumstances. On the one hand, he frequently articulates the need for a form of collective responsibility and developmental leadership from the grass roots. Hence, one reason for the move to armed struggle was the fact that this was happening anyway as Black South Africans were forming their own military units. Consequently, the ANC needed to be the organization directing their actions. In his view "We have always maintained that the people were ahead of us, and now they were" (1994, p. 272). Contrarily, however, he also argued that leadership sometimes involved individual leaders moving against an already agreed upon and articulated collective policy. An example of this was the deliberate break he made with ANC policy when he gave a 
statement to the local and national South African press in May 1961 stating that the ANC was now closing the chapter on nonviolent policy and moving into a different phase of the struggle - armed resistance. As Mandela acknowledged "It was a grave declaration and I knew it. I was criticized by our executive for making that remark before it was discussed by the organization, but sometimes one must go public with an idea to push a reluctant organization in the direction you want it to go” (1994, p. 270).

In choosing sabotage against power stations, arms depots and communications systems the ANC was strategizing for what would happen after apartheid was removed. The choice of sabotage was deliberated and considered, based on the assumption that a strategy involving the smallest loss of life would have the widest favorable reception. Mandela wrote "Because it did not involve loss of life it offered the best hope for reconciliation among the races afterward. We did not want to start a blood feud between white and black. Animosity between Afrikaner and Englishman was still sharp fifty years after the Anglo-Boer war; what would race relations be like between white and black if we provoked a civil war? Sabotage had the added virtue of requiring the least manpower" (1994, pp. 282-283). In testimony during his 1964 trial he denied that the ANC had been preparing for guerilla war, but did not deny his planning of sabotage. As always, he maintained external forces had impelled these strategic choices in the fight for freedom. The decision was one forced on him by the government; "I did not plan it in a spirit of recklessness nor because I have any love of violence. I planned it as a result of a calm and sober assessment of the political situation that had arisen after many years of tyranny, exploitation, and oppression of my people by whites” (Mandela, 1994, p. 364). The intention "was to begin with what was least violent to individuals but most damaging to the state" (p. 274) and key to this campaign was the issuing of "Strict instructions ... that we would countenance no loss of life" (p. 283).

\section{References}

Davis, A. 1974. Angela Davis: An autobiography. New York: International Publishers. Mandela, N. 1994. Long walk to freedom. New York: Little, Brown and Company. 